\title{
UPPER JURASSIC DINOCYST STRATIGRAPHY IN THE DANISH CENTRAL TROUGH
}

\author{
N. E. Poulsen
}

Danmarks Geologiske Undersøgelse, Thoravej 8, DK-2400 Copenhagen NV, Denmark

\section{Abstract}

The English dinocyst zonations established by Woollam and Riding (1983) and Riding and Thomas (1988), and the Danish - English zonations of Davey $(1979,1982)$, are unified for the Danish North Sea area and the subzones of the Endoscrinium luridum Zone are redefined.

Two standard sections for the Upper Jurassic are described and correlations to five other wells in the Danish North Sea area are demonstrated.

\section{Zonations}

Many Jurassic dinoflagellate cyst zonations for NW Europe have been published during the last twenty years. Several are figured by Woollam and Riding (1983, fig. 9a, b). Additional data published simultaneously with or subsequent to the latter work include Davey (1982), Riley and Fenton (1982), Nøhr-Hansen (1986), Riding and Thomas (1988), Prauss (1989), Courtinat (1989).

An Upper Jurassic zonation (figs 1 and 2) is presented here for the Danish Central Trough. It is based on the work of Davey (1979; 1982), Woollam and Riding (1983), Nøhr-Hansen (1986), and Riding and Thomas (1988). Data on the stratigraphical distributions of dinoflagellate cysts from Riding (1987) and Cox et al. (1987) have also been incorporated. Some of the zones and subzones are discussed, and two subzones are revised. If correlation establishes the identity of two units, the first published name is preferred in the interest of simplicity (Hedberg, 1976 p. 20).

The standard ammonite zones are here treated as chronostratigraphic units (see Callomon, 1984; Wimbledon and Cope, 1978). The ammonite zones are referred to by the species name alone, e.g. Giganteses Zone.

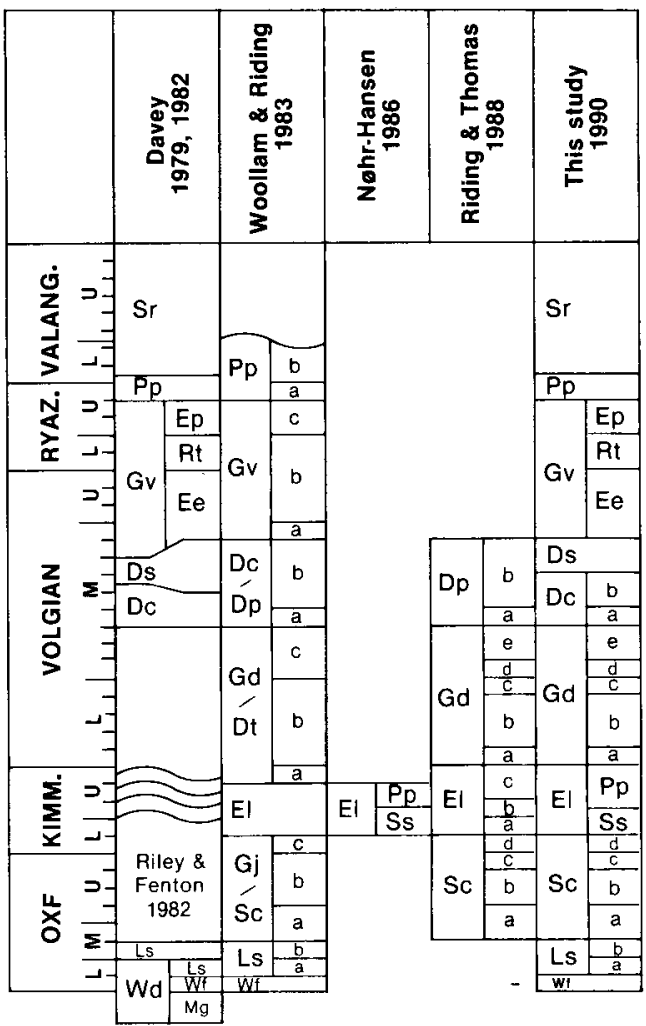

Fig. 1. Diagrammatic comparison of the proposed zonation scheme with others, published 19791988. 


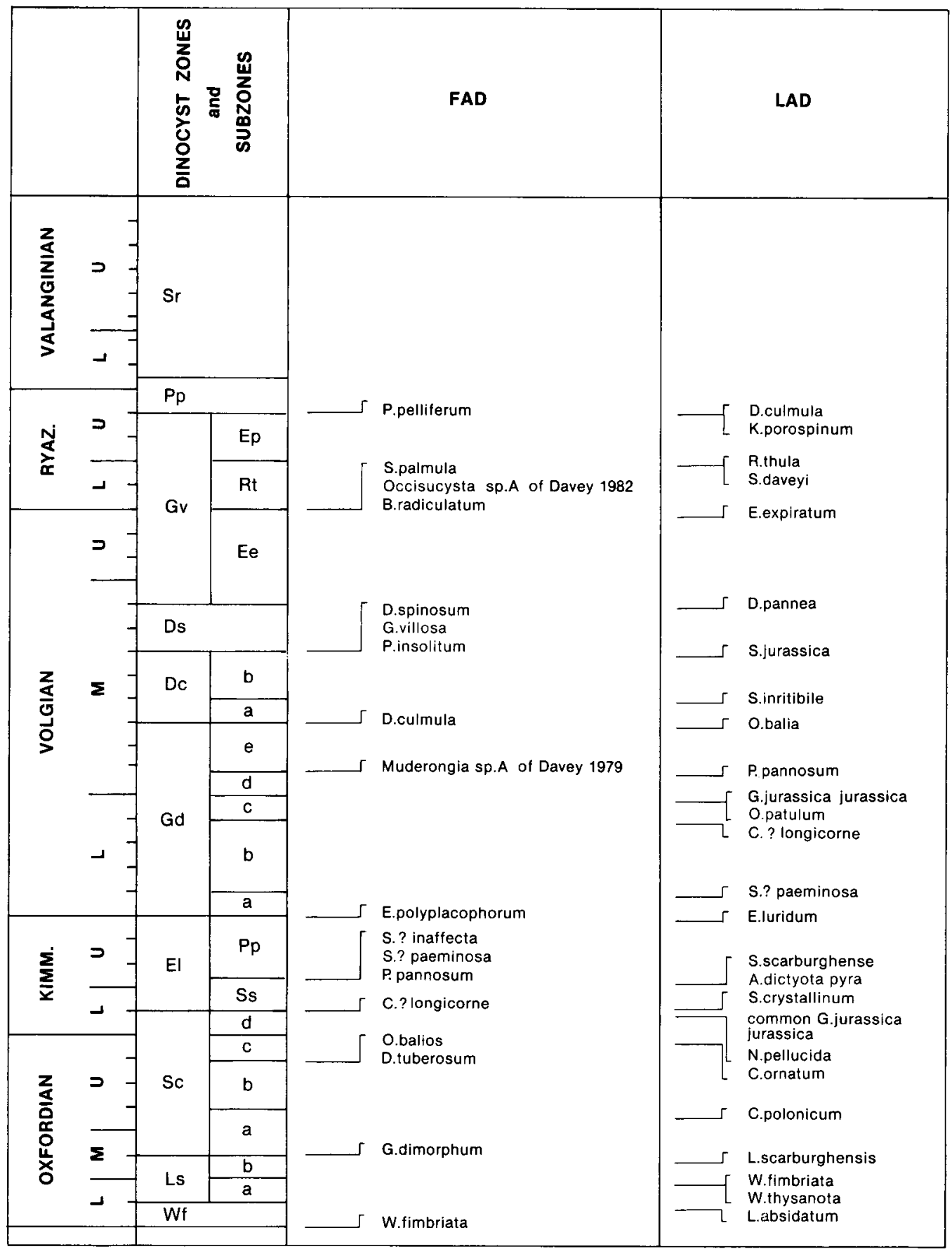

Fig. 2. Zonation scheme with first appearance datums (FAD) and last appearance datums (LAD).

\section{Zone Dc and Zone Ds}

The Dichadogonyaulax culmula Zone and the Dingodinium spinosum Zone were erected by Davey (1979). These two zones are based on the Portland Sand and the 
Portland Stone of the Dorset coastal sections (Davey, 1979). Wimbledon and Cope (1978) revised the ammonite Zones corresponding to the $D$. culmula and $D$. spinosum Zones.

Davey (1979) correlated his D. culmula Zone with the Albani and Gorei Zones (Middle Volgian). The D. culmula Zone corresponds to the Portland Sand on $\mathrm{Da}-$ vey's (1979) Dorset section. Davey (1982) subsequently correlated the $D$. culmula Zone with the Albani to mid Okusensis Zone.

The D. spinosum Zone was correlated with the Giganteus Zone (Davey, 1979) which is equivalent to the Portland Stone on Davey's (1979) Dorset section. The D. spinosum Zone was correlated with the mid Okusensis to Kerberus Zone by Davey (1982).

The Dorset section of Davey (1979, fig. 2) refers to the Purbeck section of Arkell (1933 p. 495) and Wimbledon and Cope (1978) (Fig. 3). The Portland Sand of this section was assigned to the Albani and Glaucolithus Zones (Fig. 3) by Wimbledon and Cope (1978). For this reason, the $D$. culmula Zone is correlated with these two ammonite zones. The Portland Stone of the Purbeck section is equivalent to the Okusensis, Kerberus and Anguiformis Zones (Fig. 3) (Wimbledon and Cope, 1978) and the $D$. spinosum Zone is correlated to these zones. Hence, Davey's (1979) correlations between his dinoflagellate zones and the ammonite stratigraphy are believed to be correct.

The proposed Dichadogonyaulax pannea Zone (Dp) of Riding and Thomas (1988) correlates with the Dc and Ds Zones of Davey (1979). The latter zones have publication priority and are preferred to the more recently defined Dp Zone. However, the Subzone a and the Subzone b proposed by Woollam and Riding (1983), can be considered as subzones of the Dc Zone.

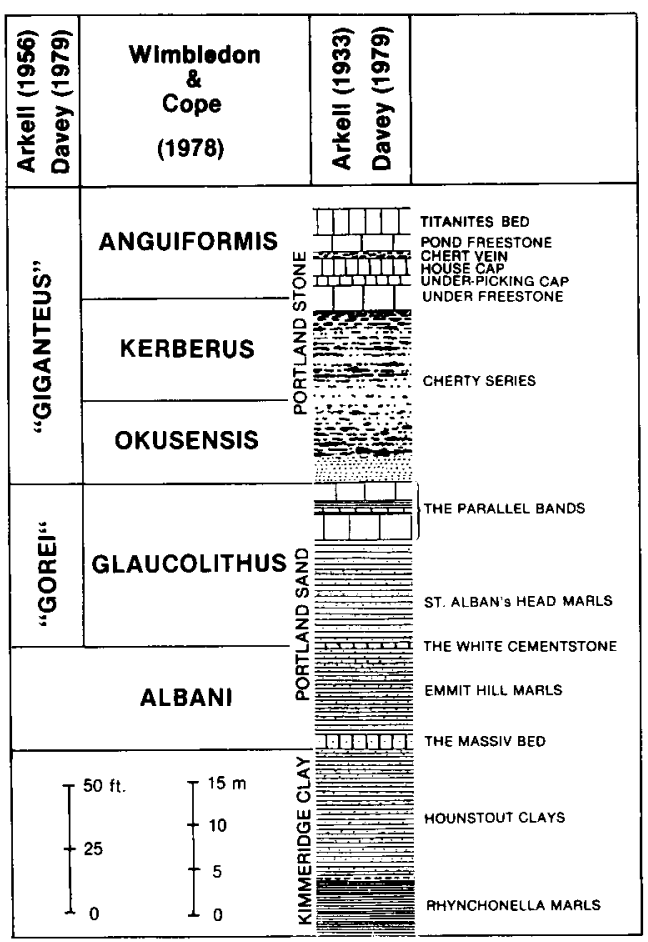

Fig. 3. Ammonite zonation of the Purbeck section, Dorset coast. After Arkell (1933, 1956), Wimbledon \& Cope (1978) and Davey (1979).

\section{The Subzone b of the Gd Zone}

The Glossodinium dimorphum (Gd) Zone, Subzone b (Lower Volgian), was defined by Riding and Thomas (1988) as the interval from the top of their Subzone a to the last appearance of Cribroperidinium longicorne. The age of the top of this subzone is the top of the Hudlestoni Zone (Riding and Thomas, 1988). However, Raynaud (1978) reported the last appearance of $C$. longicorne as within the Pallasioides Zone; $C$. longicorne is, however, never found above the Hudlestoni Zone within England (Riding, oral commun., 1990). Therefore, based on the present knowledge, the top of the proposed subzone of Riding and Thomas (1988) should be maintained at the range top of C. longicorne. 


\section{The Subzones of the El Zone}

Nøhr-Hansen (1986) proposed the Stephanelytron scarburghense and the Perisseiasphaeridium pannosum Subzones as a subdivision of the Endoscrinium luridum Zone. Riding and Thomas (1988) revised the subzones of this zone approximating the first and last appearance datums to the standard ammonite zonal boundaries. However, within the E. luridum Zone, this methodology led to an indefensible subdivision. The base of the zone is defined (Riding and Thomas, 1988) by the last appearances of Scriniodinum crystallinum, Sirmiodiniopsis orbis, and Nannoceratopsis pellucida, and the first appearances of Cribroperidinium longicorne and Oligosphaeridium patulum. The age is the base of the Cymodoce Zone (Kimmeridgian). However, Woollam and Riding (1983) reported the last appearance of $S$. orbis as the Autissiodorensis Zone (uppermost Kimmeridgian) although only indicated as rare or uncertain. Cox et al. (1987) reported the last appearance of $S$. crystallinum as Mutabilis Zone (Kimmeridgian), an occurrence which probably is related to reworking (Riding, oral commun., 1990). The species $N$. pellucida is rare in the Central Trough and is not useful for defining the zone boundary there.

Subzone a was defined by Riding and Thomas (1988) as the interval from the base of the zone to the range tops of Tubotuberella dangeardii and Endoscrinium galeritum and the range bases of Subtilisphaera? inaffecta, Subtilisphaera? paeminosa and Perisseiasphaeridium pannosum.

Age: Early Kimmeridgian, Cymodoce Chron (Riding and Thomas, 1988).

However, Woollam and Riding (1983) reported the last appearance of $E$. galeritum as Eudoxus Zone (Kimmeridgian), although they marked the last appearance as rare or uncertain. The last appearance of $T$. dangeardii was reported by Riding (1987) as Autissiodorensis Zone, but this occurrence is now believed to be related to reworking (Riding, oral commun., 1990).

The first appearances of $S$ ?. paeminosa, $S$ ? inaffecta, and $P$. pannosum reported by Riding and Thomas (1988, text-fig. 4) as mid Mutabilis Zone were also reported by Nøhr-Hansen (1986).

Subzone $b$ was defined by Riding and Thomas (1988) as the interval from the top of Subzone a to the range tops of Aldorfia dictyota subsp. pyra and Stephanelytron scarburghense.

Age: Early Kimmeridgian, Mutabilis Chron (Riding and Thomas, 1988).

However, the last appearance of $S$. scarburghense was reported by Riding and Thomas (1988, text-fig. 4) as mid Mutabilis Zone as it was reported by Nøhr-Hansen (1986). The last appearance of $A$. dictyota pyra is only indicated as the base of Mutabilis Zone (Riding and Thomas, 1988, textfig. 4). In Riding (1987, text-fig. 5) the last appearance of $A$. dictyota pyra is indicated as mid Mutabilis Zone.

The boundary between Subzone $a$ and $b$ and the boundary between Subzone $b$ and $c$ are apparently the same, i.e. mid Mutabilis Zone. The division of the E. luridum Zone proposed by Nøhr-Hansen (1986) is preferred for the Riding and Thomas (1988) alternative. The zone and the two subzones are emended.

\section{Endoscrinium luridum (El) Zone}

Revised definition: The interval from the last appearance of Nannoceratopsis pellucida Deflandre 1938 emend. Evitt 1961, the last appearance of common Gonyaulacysta jurassica (Deflandre) Norris and Sarjeant 1965 emend. Sarjeant 1982 (see Raynaud (1978) concerning common G. jurassica) and the first appearance of Cribroperidinium longicorne (Downie) Lentin and Williams 1985, to the last appearance of Endoscrinium luridum (Deflandre) Gocht 1970 and the first appearance of Egmontodinium 


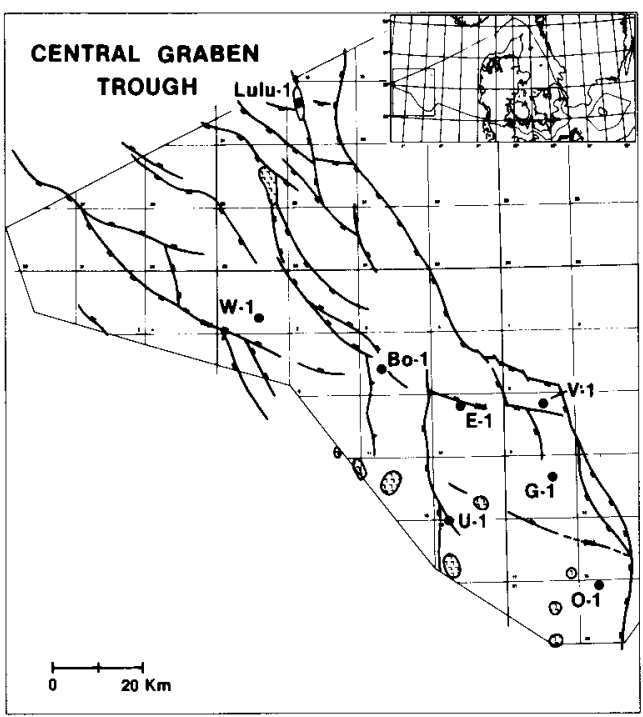

Fig. 4. Location map.

polyplacophorum Gitmez and Sarjeant 1972.

Age: Base of the Cymodoce Chron to the top of the Autissiodorensis Chron (Kimmeridgian).

\section{Stephanelytron scarburghense (Ss) Subzone}

Revised definition: The interval from the base of the zone to the last appearance of Aldorfia dictyota subsp. pyra (Gitmez) Davey 1982 and Stephanelytron scarburghense Sarjeant 1961 emend. Stover et al. 1977 and the first appearence of Perisseiasphaeridium pannosum Davey and Williams 1966, Subtilisphaera inaffecta (Drugg) Bujak and Davies 1983, Subtilisphaera paeminosa (Drugg) Bujak and Davies 1983.

Age: Cymodoce to mid Mutabilis Chron (Kimmeridgian).

\section{Perisseiasphaeridium pannosum (Pp) Subzone}

Revised definition: The interval from the top of the Ss Subzone to the top of the zone.
Age: Mid Mutabilis to Autissiodorensis Chron (Kimmeridgian).

Comments: There is no stratotype selected for the zone. However, the boundary between the two subzones was first described by Nøhr-Hansen (1986) at the clay-pit of Blue Circle Portland Cement, at Westbury, in Wiltshire, England.

Regional aspects: The zone and the two subzones are defined for, and found in the United Kingdom. The zone and at least the Pp Subzone are found in the Central Trough. The zone and the Pp Subzone are also present in the Danish Subbasin, both in several wells in Jutland and in wells in the Sound (between Denmark and Sweden). It is currently uncertain if the Ss Subzone is present in the Danish Subbasin. The zone is also present in East Greenland and again the Pp Subzone is recognized (Piasecki, 1980).

\section{Standard sections and correlations}

Two wells, U-1 and E-1 (figs 4 and 5), were chosen by the Geological Survey of Denmark in cooperation with the Geological Institute of the University of Copenhagen as standard section of the Upper Jurassic of the Danish Central Trough. The U-1 well represents the transition from the Middle Jurassic to the Upper Jurassic, and the lower part of the Upper Jurassic, i.e. the Lower Graben Sand, the Middle Graben Shale, the Lola Formations and the lower part of the Farsund Formation. The upper part of the Farsund Formation is missing, probably due to salt-tectonic movements. The well E-1 represents the uppermost Jurassic. More Jurassic strata are probably present, but are not penetrated in this well. 


\section{$U-1$}

The Lower Graben Sand Formation was dated as Late Callovian by Hoelstad (1986). Common Mendicodinium groenlandicum at the base of the Lola Formation allow a possible correlation to the uppermost Callovian (Riley and Fenton, 1982). The last appearances of Ctenidodinium continuum at 10470 feet allow a correlation to the Wanaea fimbriata Zone (Piasecki, 1980). The last appearance of Gonyaulacysta jurassica "hlanc" (unpublished subspecies of Poulsen, in prep. (a)) at 10420 feet is referred to the Liesbergia scarburghensis Zone, Subzone a.

At 9990 feet Scriniodinium crystallinum Zone, Subzone a is marked by the last appearances of Systematophora valensii and Compositosphaeridium polonicum. The occurrence of Atopodinium prostatum in the sidewall core at 9806 feet allows its correlation with the $S$. crystallinum Zone, Subzone b. The last appearance of Ctenidodinium ornatum at 9740 feet indicates of correlation of this level to the $S$. crystallinum Zone, Subzone c. This subzone indicates the top of the Oxfordian. The occurrence of Dingodinium tuberosum together with common $\mathrm{Go}$ nyaulacysta jurassica in the sidewall core at 9690 feet permits a correlation to the $S$. crystallinum Zone, Subzone d. This subzone indicates the base of the Kimmeridgian. The Oxfordian - Kimmeridgian boundary is in this well found in the uppermost part of the Lola Formation.

All samples of the Farsund Formation in this well are correlated to the Endoscrinium luridum Zone. The occurrence of $E$. luridum, Endoscrinium galeritum, and Perisseiasphaeridium pannosum in the uppermost sidewall core of the Farsund Formation assigns this level to the $E$. luridum Zone, $P$. pannosum Subzone.
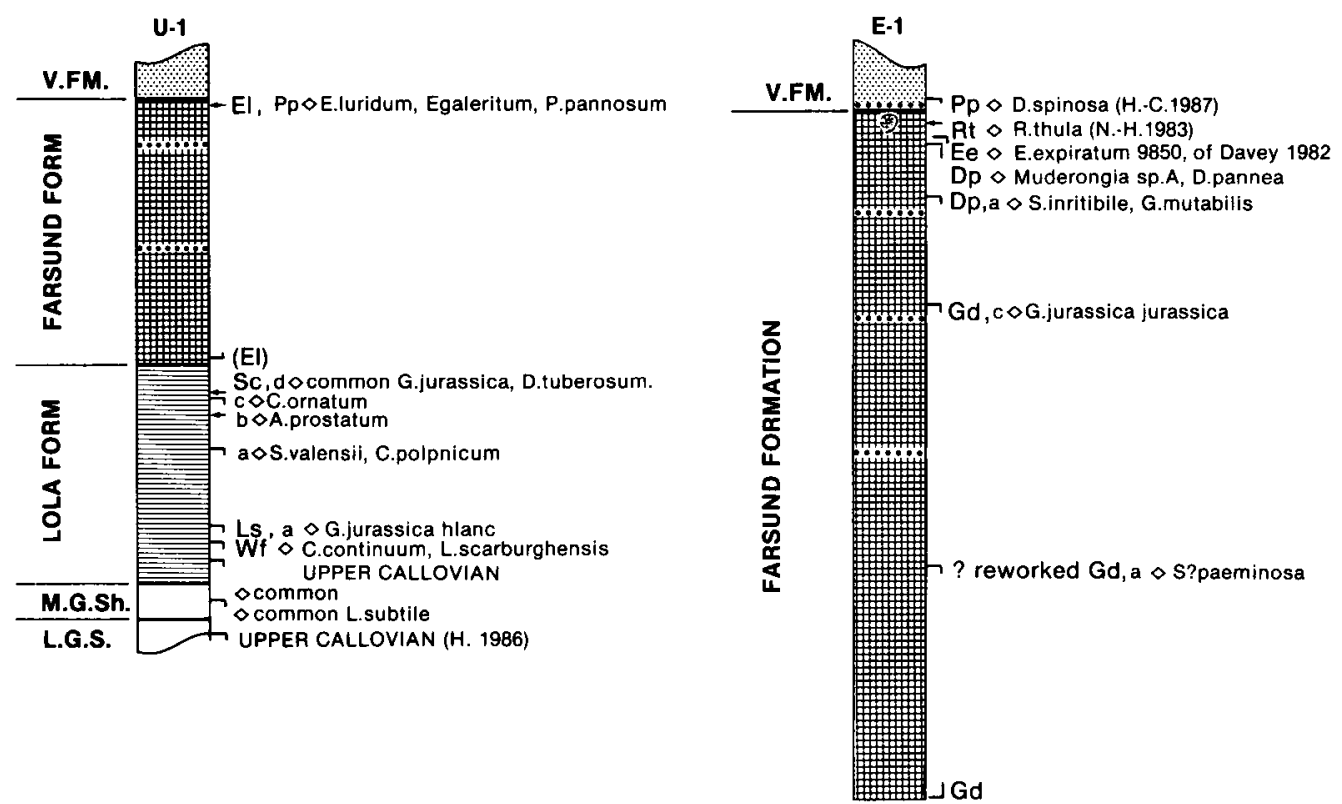

Fig. 5. Zonation of the wells $U-1$ and E-1. Zones and subzones are given in abbreviations, followed by index species. H. $1986=$ Hoelstad, 1986; H-C, $1987=$ Heilmann-Clausen, 1987; N-H, $1983=N \varnothing h r-$ Hansen, 1983. 


\section{E-1}

The last appearance of $G$. jurassica at 10750 feet permits a correlation to the Glossodinium dimorphum Zone, Subzone c, Lower Volgian. The underlying subzones $b$ and a or Zone El were not traceable. The occurrence of Subtilisphaera? paeminosa at 12050 feet is believed to be related to reworking. Subtilisphaera? paeminosa has its last appearance in the G. dimorphum Zone, Subzone a, lowermost Volgian, which apparently is not present in this well.

The last appearance of Scriniodinium inritibile and Gochteodinia mutabilis at 10190 feet is referred to the Dichadogonyaulax panneum Zone, Subzone a, Middle Volgian.

The last appearance of Muderongia sp. A of Davey 1982 and D. pannea at 9890 feet places this level at the top of the $D$. panneum Zone, Middle Volgian.
The last appearance of Egmontodinium expiratum at 9850 feet permits the correlation to the Gochteodinia villosa Zone, E. expiratum Subzone, uppermost Middle to Upper Volgian (Nøhr-Hansen, 1983).

The report of Rotosphaeropsis thula at 9783 feet close to the top of the Farsund Formation (Nøhr-Hansen, 1983) allows a correlation to the G. villosa Zone, $R$. thula Subzone, Lower Ryazanian.

The recorded last appearance of Dingodinium spinosum at the base of the Valhall Formation at 9690' (Heilmann-Clausen, 1987) permits a correlation to the Pseudoceratium pelliferum Zone, uppermost Ryazanian.

\section{Correlations}

Investigations of dinoflagellate cysts (Poulsen, in prep. (b)) have made biostratigraphical correlations between the O-1, U-1, G-1,
LEGEND:

..... Seismic correlation

- Biostratigraphic correlation
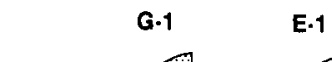

Bo-1

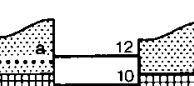

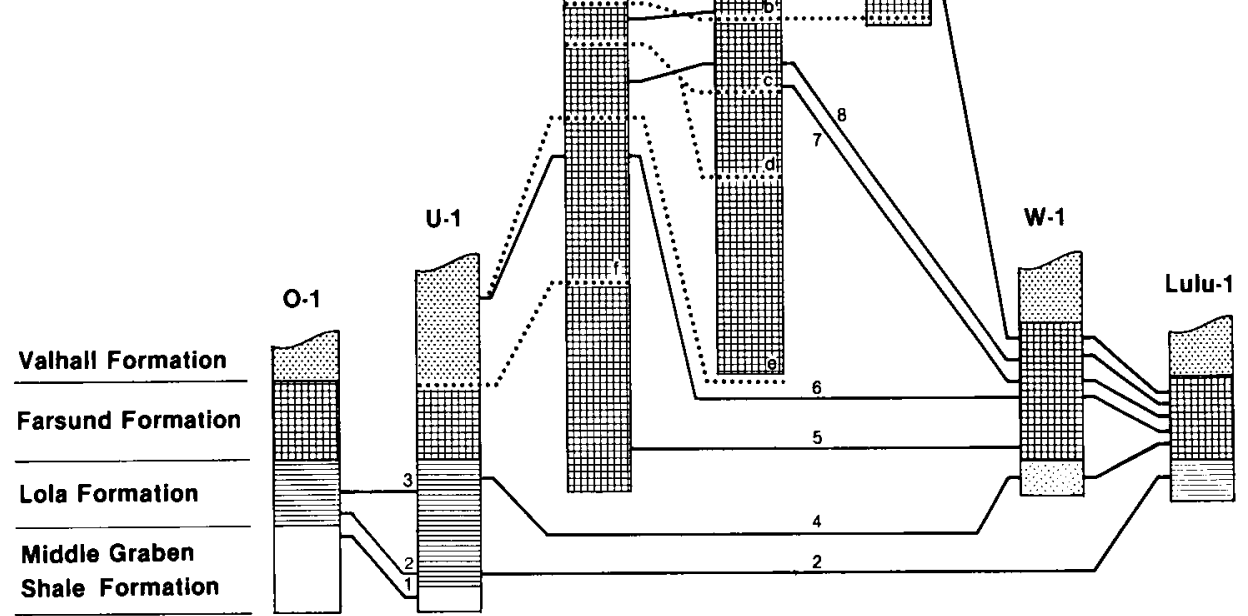

Fig. 6. Correlation between the wells $O-1, U \cdot 1, G-1, E-1, B o-1, W-1$ and Lulu-1.

Biostratigraphic correlations

1. Late Callovian, 2. Early Oxfordian (Wf-Ls), 3. Middle Oxfordian Sc, a), 4. Late Oxfordian (Sc, c), 5 . earliest Kimmeridgian (El/Sc), 6. Late Kimmeridgian ( $E l, P p)$, 7. early Middle Volgian $(G d, c)$, 8. early Middle Volgian $(G d, d)$, 9. mid Middle Volgian $(D c)$, $9 a$. mid Middle Volgian $(D c, a), 10$. Late Volgian $(G v, E e)$, 11. Early Ryazanian $(G v, E p), 12$. Late Ryazanian $(P p)$. (Abbreviations in parentheses $=$ zone, subzone).

Seismic correlations

(Mфller, 1986) $a=L C U, b=U J 7, c=U J 6, d=U J 5, e=U J 3, f=U J 2$. 
E-1, Bo-1, W-1, and Lulu-1 wells possible (Fig. 4). On Fig. 6 the biostratigraphic correlations are shown in full lines. Seismic correlations after Møller (1986) are shown in dotted lines. As the figure demonstrates, seismic and biostratigraphic correlations are in many cases isochronous.

\section{Acknowledgements}

I am grateful to Dr. James Riding, at the British Geological Survey, who kindly read an early draft of this manuscript and gave constructive criticism and suggested ways of its improvement.

I thank my colleagues at the Geological Survey of Denmark, who have been involved in preparing samples for this work, and for their help in preparing this manuscript.

The Danish Energy Ministry gave financial support (EFP-83) to the main part of this study.

\section{References}

Arkell, W. J., 1933: The Jurassic System in Great Britain. Oxford University Press, $681 \mathrm{pp}$.

Arkell, W. J., 1956: Jurassic geology of the world. Oliver \& Boyd Ltd., Edinburgh and London: 806 pp.

Callomon, J. H., 1984: Biostratigraphy, chronostratigraphy and all that - again!. In: Michelsen, O. and Zeiss, A. (eds. ), International Symposium on Jurassic Stratigraphy, Geological Survey of Denmark, 3: 611-624.

Courtinat, B., 1989: Les organoclastes des formations lithologiques du Malm dans le Jura Meridional. Systematique, biostratigraphie et elements d'interpretation paleoecologique. Documents des Laboratoires de Geologie Lyon 105, $361 \mathrm{pp}$.

Cox, B. M., Lott, G. K., Thomas, J. E. and Wilkinson, I. P., 1987: Upper Jurassic stratigraphy of four shallow cored boreholes in the U. K. sector of the southern North Sea. Proceedings of the Yorkshire Geological Society, 46, 97-109.

Davey, R. J., 1979: The stratigraphic distribution of dinocysts in the Portlandian (Latest Jurassic) to Barremian (Early Cretaceous) of Northwest Europe. American Association of Stratigraphic Palynologists, Contributions Series 5B, 49-81.

Davey, R. J., 1982: Dinocyst stratigraphy of the latest Jurassic to Early Cretaceous of the Haldager No. 1 borehole, Denmark. Geological Survey of Denmark. Series B, 6, 58 p.

Hedberg, H. D. (ed. ), 1976: International Stratigraphic guide. A guide to stratigraphic classification, terminology and procedure. A. Wiley - Interscience Publication. John Wiley and Sons, Inc., $206 \mathrm{pp}$.

Heilmann-Clausen, C., 1987: Lower Cretaceous dinoflagellate biostratigraphy in the Danish Central Trough. Danmarks Geologiske Undersøgelse. Ser. A, 17, 89 pp.

Hoelstad, T., 1986: Palynology of the Middle Jurassic Lower Graben Sand Formation of the U-1 well, Danish Central Trough. Danmarks Geologiske Undersøgelse, Ser. A, 14, 25 pp.

Møller, J. J., 1986: Seismic structural mapping of the Middle and Upper Jurassic in the Danish Central Trough. Danmarks Geologiske Unders $ø$ gelse, Ser. A, 13, 40 pp, 4 enclosures.

Nøhr-Hansen, H., 1983: In: Birkelund, T., Clausen, C. K., Hansen, H. N., and Holm, L., 1983: The Hectoroceras kocki Zone (Ryazanian) in the North Sea Central Graben and remarks on the Late Cimmerian Unconformity. Danmarks Geologiske Undersøgelse, Årbog 1982, 53-72.

Nøhr-Hansen, H., 1986: Dinocyst stratigraphy of the Lower Kimmeridge Clay, Westbury, England. Bulletin of the Geological Society of Denmark, 35 (1-2), 31-51.

Piasecki, S., 1980: Middle to Late Jurassic dinoflagellate stratigraphy from Milne Land and Jameson Land (East Greenland) correlated with ammonite stratigraphy. (Unpublished thesis, University of Copenhagen).

Poulsen, N. E., (in prep. (a)): Gonyaulacysta jurassica hlanc, a new subspecies of dinoflagellate cysts from the Early Oxfordian (Upper Jurassic) of North-west Europe and East Greenland.

Poulsen, N. E., (in prep. (b)): Callovian (Jurassic) to Ryazanian (Cretaceous) dinoflagellate biostratigraphy of the Danish Central Trough.

Prauss, M., 1989: Dinozysten-Stratigraphie und Palynofazies im Oberen Lias und Dogger von NWDeutschland. Palaeontographica Abt. B. 214, 1124.

Raynaud, J. F., 1978: Principaux dinoflagellés caractéristiques du Jurassique Supérieur d'Europe du Nord. Palinologia, número extraordinario 1, 387405.

Riding, J. B., 1987: Dinoflagellate cyst stratigraphy of the Nettleton Bottom Borehole (Jurassic: Hettangian to Kimmeridgian), Lincolnshire, England. Proceedings of the Yorkshire Geological Society, 46(3), 231-266.

Riding, J. B. and Thomas, J. E., 1988: Dinoflagellate cyst stratigraphy of the Kimmeridge Clay (Upper Jurassic) from the Dorset coast, southern England. Palynology 12, 65-88. 
Riley, L. A. and Fenton, J. P. G., 1982: A dinocyst zonation for the Callovian to Middle Oxfordian succession (Jurassic) of Northwest Europe. Palynology 6: 193-202.

Wimbledon, W. A. and Cope, J. C. W., 1978: The ammonite faunas of the English Portland Beds and the zones of the Portlandian Stage. Journal of the Geological Society of London, 135, 183-190.

Woollam, R. \& Riding, J. B., 1983: Dinoflagellate cyst zonation of the English Jurassic. Institute of Geological Sciences Report 83/2, 44 pp. 